Dear Sir,

The Royal College of Nursing and the British Psychological Society have recently set up a Joint Standing Committee to consider matters of mutual concern. One such matter which the Committee intends to discuss is the extension of the clinical role of the nurse, with particular reference to developments in behaviour therapy and behaviour modification. My purpose in writing is to invite individuals and bodies to make their views on this subject known to the Committee, by writing to Mr. P.D. Mellor, Royal College of Nursing, Henrietta Place, London. W1M OAB.

Yours faithfully,

Frank M. McPherson,

Chairman, Rcn/BPS Joint Standing Committee.

Royal Dundee Liff Hospital.

\title{
Dear Sir ,
}

It is unfortunate that the Association has moved from recommendations to a working party to a commitment to an ethical code that is binding on its membership (Chairman's message, Bulletin, 1978, 6, 19) without consulting its members directly, especially since it does not have an ethical code. One wonders whether the Executive's policy (Bulletin, 1977, 5, 8-12) has not finally led up a blind alley.

The statement to which Dr. Whitehead refers (Bulletin, 1976, 4, 49-52) certainly addresses some of the major issues, though some of its recommendations seem not to reach the heart of the matter and others are surely controversial. My own feeling is that the AABT "Ethical issues for human services"' (Bulletin, 1977, 5, 110-111) provides a much more practical approach. However, as Dr. Whitehead suggests, if registration were to hinge on membership of a registered organisation, the real problem is not the minutiae of the code but how the organisation is to undertake the control of its membership. Admission to membership might have to involve a bit more than being acceptable to CCETSW, the B.Ps.S. or the Royal College of Psychiatrists. and quite an elaborate machinery might be required to investigate complaints against members.

Perhaps the way forward lies in considering how a patient or indeed any member of the public can hold any therapist to account - those describing themselves as psychotherapists being just a special case of the general issue. Admittedly this is a complex question since as a result of the medical profession's insistence on the independence of clinical judgement, the procedures by which medical therapists can be held to account by their patients are complex and expensive. On the whole questions have not been raised about non-medical therapists in the NHS because of a convention about the significance of medical referral. Outside the NHS, members of the public apparently have even less opportunity to seek redress in the case of malpractice. Yet the law, though rather cumbersome in operation, does in fact provide some basis for defence 
against many of the practices which, as BABP have argued, are unethical.

It is perhaps in this area that BABP, as a multidisciplinary organisation, could make a real contribution to the practice of several professions, by getting a lawyer to draw together all the legal aspects of confidentiality, responsibility, misrepresentation of benefits from treatment etc. One has in mind the liabilities arising out of common law e.g. relating to negligence, statutory duties, trespass to the person, privacy and so on not to mention any statutory limitations that may be set by the Trades Descriptions Act or whatever. This would be both a useful and an important step since these legal aspects constitute an implicit code of professional practice that already exists and any binding professional standards proposed by BABP could only make them explicit or add to them.

Yours faithfully,

Bernard Kat

Senior Clinical Psychologist

St. Georges' Hospital, Morpeth, Northumberland.

\section{Dear Sir,}

I found Mr. Kat's letter interesting and useful but was somewhat intrigued by the first paragraph. We cannot, of course, bind the membership to an ethical code without consultation - this would require a constitutional change which would have to be considered by the membership at an A.G.M. Also, surely Mr. Kat's very letter is in response to the request for feedback. In addition, he says that he wonders "whether the Executive's policy (i.e, on the Registration of Psychotherapists) has not finally led up a blind alley". He may well be right but must, I fear, accept that this is actually the Association's policy since it was passed as acceptable at the last A.G.M.; personally, I should more than welcome viable alternative suggestions since the Report will shortly be published which will increase the amount of public debate. So, any ideas?

Antonia Whitehead, B.A.B.P. Chairman. 